\title{
Effective Prosecution of Hate Crimes as a Precondition for Their Prevention
}

\section{Nefret Suçlarının Önlenmesi için Ön Koşul Olarak Etkili Kovuşturma}

\section{Besa ARÍFi ${ }^{10}$}

${ }^{1}$ Assoc. Prof., South East European University, Tetovë, Republic of Macedonia

\section{ABSTRACT}

The most serious problem in regard to dealing with hate crime in Macedonia is the fact that in the majority of cases, these crimes are not presented as hate crimes but as "normal" crimes lacking the recognition of the true motivation behind them. Thus the official hate crime rate in this country typically does not represent the true situation.

This article will analyze the importance of effective prosecution of hate crimes, both for the recognition of the problem and for future prevention of these crimes. It is evident that without institutional action these crimes will not only continue to happen, but they will also continue to be "hidden" from the official data, which unfortunately, does not solve but rather complicates the problem.

The article will analyze the legal regulation of hate crimes in Macedonia and the efforts that are being made to provide better legislation with the aim of effectively prosecuting such crimes. The official and shadow reports will be analyzed in a desk research method and comparison will be made in regard to the prosecution of hate crimes in the regional countries. Conclusions and recommendations will offer ideas about how the legislative amendments and solutions found in comparative practice can contribute to improvement in regard to prosecuting hate crimes in Macedonia.

Keywords: Hate crimes, hate speech, prosecution

\section{Öz}

Makedonya'da nefret suçlarıyla mücadele konusunda en ciddi sorun, bu tür vakaların çoğunlukla nefret suçları olarak değil, adi suçlar olarak değerlendirilip suçun arkasındaki gerçek saikin tanınmamasından kaynaklanmaktadır. Bundan dolayı, çoğu zaman ülkedeki resmi rakamlara göre nefret suçu oranı gerçek durumu yansıtmamaktadır.

$\mathrm{Bu}$ makale, nefret suçlarının sorunun tanınması ve gelecekte bu suçların önlenmesi için etkili bir biçimde kovuşturulmasının önemini analiz edecektir. Kurumsal yaklaşım olmaksızın, bu suçların sadece devam etmesi değil, aynı zamanda bu tür suçların resmi verilere görünür olmamasıyla birlikte sorunun çözülmesi yerine maalesef daha karmaşık hale getirmektedir.

Makalede, Makedonya'daki nefret suçlarının yasal düzenlemeleri ve nefret suçlarının etkili bir şekilde kovuşturma amacı ile daha iyi bir mevzuat sağlanması yönündeki çabaları incelenecekir. Resmi ve resmi olmayan raporların taraması yapılıp analiz edilecek ve bölgesel ülkelerdeki nefret suçlarının kovuşturulmasıyla karşılaştırması yapılacaktır.

Sonuçlar ve tavsiyeler, karşılaştırmalı araştırma sonucu ortaya çıkan yasal değişiklikler ve çözümlerin Makedonya'daki nefret suçlarının kovuşturulmasıyla ilgili gelişmelere nasıl katkıda bulunabileceği konusunda fikir sunacaktır.

Anahtar Kelimeler: Nefret suçları, nefret söylemi, kovuşturma 


\section{Introduction}

Hate crimes that are not properly prosecuted and punished represent a serious threat to the interpersonal, inter-ethnic and inter-confessional relations in a country. Failure of state institutions to prosecute such crimes indicates that the state is willing to tolerate them. Tolerance shown towards hate crimes creates marginalised groups and communities who distance themselves from the state institutions because of the feeling that they are not appropriately protected by the institutions that should guarantee their protection. This lack of trust in institutions creates many other problems which emerge from the marginalization and discrimination of a group of people.

Hate crimes are a reality in every country. Every state encounters different types and intensities of hate crimes. However, states differ among themselves in regard to their policies on prosecuting such crimes. Some states show clear intent and action aiming at the prosecution of these crimes. They make a distinction between these crimes and others, both in their legislation, and also in the way they implement their prosecution, putting them into the hands of the state institutions eligible to prosecute crimes. They create separate mechanisms with the particular intention of prosecuting hate crimes and they work closely with communities who usually appear as victims of these crimes.

Other states choose to ignore the problem of hate crime not wanting it to interfere with the relations between different communities. In fact, the decision to ignore hate crime and pretend it does not exist is what interferes with these relations and creates the above-mentioned lack of trust in state institutions. Therefore, ignoring the situation will not solve the problems related to hate crime but will only create new ones.

When we talk about the importance of tolerance in a multi-ethnic and multiconfessional society, we need to understand that tolerance is not a mere definition neatly written on paper that looks good when recited on important dates. Tolerance means serious action leading to the creation of an environment free of discrimination and marginalization, where the concept of the rule of law prevails. Tolerance means showing zero tolerance for any act that interferes with good relations among communities. Tolerance means fair and just prosecution of hate crimes.

This article will discuss the approach towards hate crimes, the importance of their 
prosecution, as well as new developments in regard to amending the legislation and changing the traditional approach towards prosecuting hate crimes.

\section{Current Legal Provisions and their Implementation in Practice}

Between the years 2009 and 2014 amendments were made to the Criminal Code of RM (in force since $1996^{1}$ ) which introduced the concept of hate crimes in the positive criminal law of this country, concretely in article 39 paragraph 5, which reads:

[w]hen determining the sentence, the court shall especially consider whether the crime has been committed against a person or group of persons or property, directly or indirectly, because of his/her sex, race, color of skin, gender, belonging to a marginalized group, ethnic origin, language, citizenship, social origin, religion or religious belief, other beliefs, education, political adherence, private or social status, mental or physical disability, age, family and marital status, property status, health condition, or any other ground provided in law or ratified international agreement. $^{2}$

This kind of qualified sentencing and the above mentioned protected characteristics of the victim are further mentioned in articles 137/1, 144/4, 319/1, 394g/1, 417/1 of this Criminal Code which consequently criminalizes violation of equality between citizens, endangering of security, causing of hatred, division or intolerance on the basis of national, racial, religious and other form of discrimination, distribution of racist and xenophobic material through a computer system, and racial and other forms of discrimination. As explained by Kambovski the aim of this provision includes both the prevention of hate crimes as well as sending an institutional message that they will not be tolerated in this society. ${ }^{3}$

However, legal provisions that are merely written in the text of criminal law but are not implemented in practice hardly have any value. Although the concept of hate

1 Kanevcev, Metodija, Criminal Code - updated integral text (Stobi Trejd: (2015).

2 Criminal Code of RM (Please erase the words in brackets), adopted in 1996, Official Gazette of RM nr. 37/1996, amended in O.G. nr. 80/99, 04/02, 43/03, 19/04, 81/05, 60/06, 73/06, 7/08, 139/08, 114/09, 51/11, $51 / 11(2), 135 / 11,185 / 11,142 / 12,166 / 12,55 / 13,82 / 13,14 / 14,27 / 14,28 / 14,132 / 14,160 / 14,199 / 14$, $196 / 15,226 / 15$.

3 Kambovski Vlado (2015) Proposal for the formation of a working group for the revision of the legal provisions concerning hate crimes and preparation of recommendations for their implementation by comptetent institutions. Skopje: Unpublished internal document prepared for the National Working Group on Hate Crimes. 
crime was introduced in 2009, the problem, well established by the civil sector, is that hate crimes are not differentiated as such in the judicial practice of RM and therefore, persons who commit them, are usually only charged or convicted for 'normal' crimes without the bias element that differentiates them as hate crimes. Thus, a simple search in the OSCE official website on hate crimes ${ }^{4}$ will show that in RM there are no official data in regard to numbers of charged, prosecuted or convicted persons in regard to this form of crime. The reason for this is the lack of an efficient mechanism in the institutions of police, prosecution and judiciary to identify hate crimes and categorize them as such. Moreover, the Helsinki Committee for Human Rights of RM, supported by the OSCE, has been developing a separate program on hate crimes since 2013, and since then, it has been following incidents that have elements of hate crime. The results are published in their annual reports ${ }^{5}$ as well as on the web site which specializes in hate crimes ${ }^{6}$. These reports and the information on the updated web-site indicate that since 2013, a total number of 286 hate crime incidents have occurred, the majority of which fall into the category of ethnical belonging or citizenship (183), with the remaining fitting into the classifications of political affiliation or political belief (33), refugee or migrant status (30), inciting national, racial or religious hatred, discord or intolerance (23), religious affiliation or religious belief (20), sexual orientation or gender identity (18), and such like ${ }^{7}$. Moreover, the reports of the Helsinki Committee clearly indicate that according to their monitoring of the court proceedings that involve hate crime incidents, it is frequently noted that these crimes are not appropriately investigated and many perpetrators are either not identified or they are not found guilty, or alternatively, convicted to minor sentences ${ }^{8}$. These indications demonstrate that hate crimes are evident in RM showing clear characteristics despite the lack of official reporting by state institutions. Thus, ignoring this fact will not make these crimes go away. On the contrary, as held by the European Court of Human Rights:

4 http://www.hatecrime.osce.org/former-yugoslav-republic-macedonia

5 Helsinki Committee for Human Rights in RM (2015) and Helsinki Committee for Human Rights in RM (2014).

6 www.zlostorstvaodomraza.com

7 For accurate information please consult the following link: http://www.zlostorstvaodomraza.com/ reports?1=en_US (accessed on August 8, 2016).

8 Thus, in an incident that occurred in Radishani-Skopje where an entire Ethnic-Albanian family experienced continuous violence and therefore was forced to leave and migrate abroad, only one person was found guilty whereas the others were not identified despite the security camera footages. More information on this case and other incidents followed by Helsinki Committee can be found in their Annual Report on Hate crimes of 2014. (Helsinki Committee for Human Rights in RM, 2014). 
[w]hen investigating violent incidents, such as ill-treatment, State authorities have the duty to take all reasonable steps to unmask possible discriminatory motives. Treating violence and brutality with a discriminatory intent on an equal footing with cases that have no such overtones would be turning a blind eye to the specific nature of acts that are particularly destructive of fundamental rights. ${ }^{9}$

\section{International Recommendations and the Formation of the National Working Group on Hate Crimes, and Draft Amendments to the Criminal Code of RM}

In this regard, it is very important that some recommendations made by international organisations are mentioned. For example, the 2014 Report of the Working Group on the UN Universal Periodic Review recommends RM to "[f]ight impunity for violence against marginalized persons motivated by their ethnicity, religion, or sexual orientation, particularly through an improved awareness of public opinion, and the police and judicial authorities." ${ }^{" 10}$ Moreover, the EU Progress Reports on Macedonia for the year 2013 state that: "[d]ata on the reporting, investigation and prosecution of hate speech and hate crime is not collected systematically and training of law enforcement, prosecutors and judges needs to be stepped up" ${ }_{11}$ and with the situation not changing in $2014{ }^{12}$ nor in 2015 , they conclude that "Collection of data on the reporting, investigation and prosecution of hate speech and hate crime is still not systematic and several cases of hate speech in social media and blogs require adequate follow-up by the authorities". ${ }^{13}$

Due to this lack of progress, in 2015 the OSCE Mission in Skopje in cooperation with the Macedonian Academy for Sciences and Arts (hereafter MASA), led at that time by Academic Vlado Kambovski, worked together on creating a National Working Group on Hate Crimes consisting of representatives from the following

9 Identoba and Others v. Georgia, 2015, ECtHR, par. 67.

10 Recommendation 101.40 made by Belgium, Human Rights Council, Report of the Working Group on the Universal Periodic Review - The former Yugoslav Republic of Macedonia (26 March 2014), page 18, available at http://www.ohchr.org/EN/HRBodies/UPR/Pages/MKSession18.aspx (accessed on August 8, 2016) " (UN General Assembly, Human Rights Council, 2014, p. 18).

11 The European Commission. (2013, October 16). The Former Yugoslav Republic of Macedonia 2013 Progress Report, p. 45.

12 The European Commission. (2014, October 8). The Former Yugoslav Republic of Macedonia 2014 Progress Report, p. 47.

13 The European Commission. (2015, November 11). The Former Yugoslav Republic of Macedonia 2015 Progress Report, p. 59. 
institutions: the Faculty of Law, the Ministry of Justice, the Ministry of Interior Affairs, the Office of the Prosecution, the Judiciary, the National Contact Person for Hate Crimes by the Ministry for Foreign Affairs, the Academy for Judges and Public Prosecutors, the Civil Society Sector (Helsinki Committee), the Academic Community, the National Commission on Anti-Discrimination, MASA and the Macedonian Society for Criminal Law and Criminology. ${ }^{14}$ The author of this paper is a member of the National Working Group on Hate Crimes (hereafter NWGHC). The group has worked on preparing draft amendments to the Criminal Code of RM which aim at a better definition of hate crimes in different articles of the Code. A separate definition is to be established in article 122 paragraph 23 that will define a hate crime as:

... [a] criminal act against a person or legal entity or property related to it, that is committed entirely or partially because of the actual or presumed characteristic of the person that refers to race, color of skin, national and ethnic belonging, religion or religious belief, mental or physical disability, sex or gender identity, sexual orientation, political affiliation, age or belonging to a marginalized group. ${ }^{15}$

The definition will refer to the remaining article 39 paragraph 5, as cited above, when prescribing aggravating circumstances in cases of a crime having the bias element. Moreover, the previous list of separate crimes where the bias element will continue to represent an aggravating circumstance is to be enlarged according to the proposed draft amendment in order to include the following crimes that will include an additional aggravating circumstance when committed out of hate: murder (article 123), bodily injury (article 130), severe bodily injury, (article 131), coercion (article 139), unlawful deprivation of liberty (article 140), torture and other cruel, inhuman or degrading treatment and punishment (article 142), threatening safety (article 144), prevention or disturbance of public gathering, (article 155), rape (article 186), sexual assault of a helpless person, (article 187), sexual assault upon a child under the age of 14 (article 188), not providing medical help, (article 208), damage to objects of

14 Kambovski, V. (2015). Proposal for the formation of a working group for the revision of the legal provisions concerning hate crimes and preparation of recommendations for their implementation by competent institutions. Skopje: Unpublished internal document prepared for the National Working Group on Hate Crimes.

15 Kambovski, V. (2016). Draft-amandments on the provisions of the Criminal Code that refere to hate crimes. Skopje: Unpublished internal document prepared for the National Working Gorup on Hate Crimes. 
others (article 243), abuse of official position and authorization, (article 353), act of violence (article 386), and desecration of a grave (article 400).

\section{Recommendations by OSCE-ODIHR in regard to the Draft Amendments of the Criminal Code of RM}

The proposed draft amendments were thoroughly reviewed by the OSCE-ODIHR and a detailed feedback report was received with comments and recommendations that are currently in the process of adjustment by the NWGHC. The OSCE-ODIHR 2016 feedback report found that the two tier approach, namely that of using Article 39 paragraph 5 in parallel with the approach of crimes committed out of hate, should be enlarged, in order to include a larger list of crimes and provide better possibilities of identifying and prosecuting hate crimes. The OSCE-ODIHR further recommend to the Macedonian Authorities "to specify in law that judges are obliged to put on record the reasons for applying or not applying the provision of Article 39 para. 5 of the current Criminal Code in cases which involve potential bias motives on the part of the perpetrator." ${ }^{16}$ They also recommend some fine-tuning adjustment of the old and new articles and paragraphs in order to provide a clear understanding of the concept of hate crimes and better implementation of the rules incriminating hate crimes. It is also interesting that the feedback report found that:

[i]n the case of political affiliation, it is noted that while this ground is sometimes included as a protected characteristic in domestic legislation, it is not an immutable or fundamental characteristic and can often change over time. Additionally, it is a vague term open to various interpretations and potentially very difficult to prove in practice. For this reason, it is recommended to remove political affiliation as a protected characteristic from the Draft Amendments. ${ }^{17}$

However, it is important to note that Macedonia currently represents an extremely politicized society, and as explained by the reports cited above, hate crimes related to political affiliation or political belief are the second largest category of hate crimes committed in RM. Therefore, the political affiliation and political belief categories

16 OSCE-ODIHR. (2016). Comments on Draft Amendments to Certain Provisions of the Criminal Code of the Former Yugoslav Republic of Macedonia Regarding Bias-Motivated Crimes based on an unofficial English translation of the draft amendments provided by the OSCE Mission to Skopje. Warsaw: OSCEODIHR, p. 10.

17 OSCE-ODIHR, 2016, p. 13. 
should be thoroughly discussed and seriously considered in the amendments taking into account the specific situation of this country. It would send the message that hate crimes of any kind will not be tolerated anymore and will be properly dealt with. In this regard, it is very important that the draft amendments include 17 additional crimes which will include the element of bias in comparison with the other remaining 5 crimes that included this element from earlier amendments. It is also crucial that a specific strategy on implementation of the amendments be created that will establish appropriate mechanisms for identifying and following hate crimes through acknowledging them in the data record and in the judicial decisions.

Additionally, it is very important to relate hate crimes to the victimological approach. In this regard, the OSCE-ODIHR makes the following recommendations:

[t]o disaggregate official data on victims of crimes by ethnicity, gender, religion etc., and to supplement such data with crime victimization surveys, which may help provide insights into why individuals might be hesitant to report bias-motivated crime and learn of their experience with law enforcement agencies. ${ }^{18}$

In this context, it should be noted that in the new Law on Criminal Procedure of RM (2010, in force since 2013), there is a specific chapter ${ }^{19}$ on the victims and their rights in the criminal procedure ${ }^{20}$. However, this chapter is not implemented appropriately due to the lack of institutional capacities. Hence, as explained elsewhere ${ }^{21}$, there is no evident strategy nor are there available specialized state institutions for the implementation of the rights of crime victims in general, let alone the rights of hate crime victims.

As clearly indicated in the recommendations of OSCE-ODIHR,

[s]uccessful investigations into potential bias-motivated crimes will also depend to a large extent on society's degree of confidence and trust in law enforcement agencies and the criminal justice system. If

18 OSCE-ODIHR, 2016, p. 16.

19 Law on Criminal Procedure of RM (Please erase the words in brackets.), adopted 2010, Official Gazette of RM nr. 150/2010, amended in O.G. nr. 51/11, 100/12; Chapter V, articles 53-56.

20 Kalajdziev, Gordan; Lazetic, Gordana. (2011). Criminal Procedure Code. Academic.

21 Arifi, Besa (2015) Rights of Victims of Hate Crimes. Second International Scientific Conference, Social Change in the Global World - Proceedings (pp. 217-230). Shtip: Center for Legal and Political Research. 
institutions are seen as biased or corrupt, individuals, particularly persons from marginalized groups, are less likely to report such crimes. ${ }^{22}$

As Macedonia faces one of the largest political crises in its short history of independence ${ }^{23}$, which has brought to light serious concerns in regard to the competence, independence and legitimacy of state institutions, especially the Prosecution and Judiciary, it is notable that the lack of confidence on the part of general public is very evident, hence, it represents a fundamental problem in dealing with hate crimes.

\section{A Short Comparative Approach Towards Hate Crimes: Countries of the Balkan Region}

Taking the the data collected in the OSCE-ODIHR hate crime reporting website into consideration ${ }^{24}$ it can be noted that other countries in the region have a somewhat similar status as RM, some of them collecting and disseminating more detailed data on hate crimes that occur in their territories with others not providing sufficient information, which is also duly noted in this very useful website. Thus, it can be observed that official data by state institutions are found in Croatia, Serbia, Bosnia and Herzegovina and Slovenia, whereas no proper official data are found in Montenegro, Albania, Kosovo and Macedonia. The ODIHR has observed that Slovenia has not periodically reported reliable information and statistics on hate crimes to the ODIHR, that Croatia has not made public reliable data and statistics on hate crimes, that Bosnia and Herzegovina have not reported hate crime data disaggregated by bias motivation to the ODIHR, and that Montenegro has not periodically reported to the ODIHR the numbers of hate crimes recorded by police, Albania has not periodically reported reliable information and statistics on hate crimes to the ODIHR, whereas Macedonia does not collect data and statistics on hate crimes. There is no information available in regard to ODIHR key observations on Kosovo, although there is evident information in regard to the types of hate crime and number of incidents collected by the OSCE Mission in Pristina as well as by other NGOs. It is very indicative that only in the case of Macedonia the observation is that no data and statistics on hate crimes are officially collected, which highlights once

22 OSCE-ODIHR, 2016, p. 16.

23 One aspect of the crisis discussed in (Arifi, Besa, Presidential Pardon Debunks Fragility of Macedonian State Institutions, 2016, Balkans in Europe Policy Blog). 
again the urgent need for the adoption and implementation of the above explained draft amendments to the Criminal Court of RM as well as the application of other recommendations of the NWGHC.

The types of hate crime that are evident in the countries of the Balkan region show certain similarities in regard to the prejudices they are based in. Hence, the most evident tendency in hate crime incidents is interethnic intolerance and hatred, racism and xenophobia, in which the conflicts typically take part between the majority ethnicity and the ethnic minorities, between groups of different religious belief, as well as against the LGBT community. As previously noted, the Helsinki Committee for Human Rights of RM has indicated a high percentage of hate crimes that relate to the bias of political affiliation and political belief, which is unique to this country and is not found to such an extent in the other countries of the region. Moreover, the past years have demonstrated an increasing prejudice against refugees and migrants due to the high number of displaced persons who use the Balkan route.

It is evident that Croatia has developed a more efficient mechanism of identifying and following hate crime in comparison with other countries in the region. Due to the fact that the nature of hate crimes reported in Croatia is similar to those that occur in Macedonia (with the exception of the bias against political affiliation), as well as the fact that the general criminal law provisions are similar, the NWGHC participated in a study visit in Zagreb. ${ }^{25}$ The good practices of state institutions were noted and contacts were established to exchange information in the future. It was also noted that due to Croatia already being a member of the EU, the expectation in regard to the implementation of EU standards related to hate crime is higher. Also, the advanced development in regard to institutional capacities for following and dealing with hate crimes was evident in the specific mechanisms implemented by the Prosecution, Judiciary as well as the institutional work with the victims.

\section{The Importance of the Example of the United Kingdom in Dealing with Hate Crime}

The NWGHC conducted a comparative analysis in regard to the approach towards hate crime in the Balkans, UK and Poland. ${ }^{26}$ The author of this article conducted the

25 Agenda of the Study Visit of NWGHC in Zagreb, June 1-3. (2015). Unpublished internal document prepared for the National Working Group of Hate Crimes in RM

26 Report on the comparative analysis of national legislations on hate crimes (2015). Skopje: Unpublished internal document prepared for the National Working Group on Hate Crimes. 
research in regard to the $\mathrm{UK}^{27}$ and Poland ${ }^{28}$ and found that the UK is one of the countries that has developed very successful strategies on following, reporting and prosecuting hate crimes. The governmental hate crime action plan of 2014 known by the title "Challenge it, report it, stop it" indicates that the problem with hate crimes in the UK remains big, estimating that on average there are around 278,000 such crimes committed each year in the $\mathrm{UK}^{29}$. It also indicates the protected characteristics that typically appear in the hate crimes committed in the UK which include race, religion/ confession, disability, sexual orientation, and transgender-identity. It is interesting that the UK provides a very limited number of protected characteristics in comparison to Balkan countries, where there are usually dozens of protected characteristics in hate crime laws. For example, in the Criminal Code of RM there are 24 separate protected categories s of hate crimes in article 39 paragraph 5, whereas the Draft Amendments suggest a general definition of hate crimes where 14 protected categories are mentioned. The OSCE-ODIHR feedback report on the Draft Amendments suggested that general and unlimited categorization such as "member of a marginalized group" should be avoided due to the need for strictness of criminal law provisions. ${ }^{30}$

The most evident hate crimes in the UK involve racial and religious prejudice in the context of anti-Muslim hatred that has resulted in efforts of state institutions to work more closely with communities to tackle this problem. The action plan develops three core principles:

1) To prevent hate crime - by challenging the attitudes that underpin it, and intervening early to prevent it escalating;

2) To increase reporting and access to support - by building victim confidence and supporting local partnerships; and

3) To improve the operational response to hate crimes - by better identifying and managing cases and dealing effectively with offenders.

27 Detailed information in regard to hate crimes strategies in UK to be found in (Delivering the Government's hate crime action plan. (2014). Challenge It, Report It, Stop It. London: HM Government.).

28 Arifi Besa, Hate Crimes in UK and in Poland - A Comparative Analysis. Skopje: Unpublished internal document prepared for the National Working Group on Hate Crimes. Detailed information in regard to hate crimes strategies in Poland to be found in (Project for the American Jewish Committee Berlin . (2009). Study on National Legislative Efforts to Prevent and Combat Hate Crime. Berlin: Hogan Lovells International LLP).

29 Delivering the Government's hate crime action plan. (2014). Challenge It, Report It, Stop It. London: HM Government, p. 6.

30 OSCE-ODIHR, 2016, pp. 14-15. 
These three pillars of the UK action plan on hate crime should be used as an example of good practice when creating a national strategy for prevention and punishment of hate crimes in Macedonia. The most important thing to be learned is the understanding that no state can afford to ignore hate crimes by not making efforts to better identify and acknowledge them. Another important attitude is the early intervention and prevention of escalation, which again is not very evident in Macedonia, bearing in mind the lack of efficiency of state institutions to effectively deal with these situations and to better identify and manage hate crime cases. Moreover, the importance of working with the victims and building their confidence in the state institutions is crucial for reporting hate crimes and it is not a coincidence that it was also emphasized in the OSCE-ODIHR recommendations. Moreover, the incidents reported by the Helsinki Committee for Human Rights often demonstrate the hesitation of the victims to report hate crimes due to the lack of confidence in state institutions. Efforts should be made to provide better protection for victims of hate crimes and to help them deal with the consequences through effectively managing the case due to legal provisions.

\section{Conclusion}

This article has established the importance of prosecuting hate crimes in multiethnic societies. The fact that Macedonia has not yet developed a comprehensive mechanism of officially identifying and prosecuting hate crimes as such raises serious concerns. Although penalized in the criminal code of RM, there is no official data on the amount of such crimes committed neither are there judicial verdicts that condemn the commission of hate crimes, rather, they are prosecuted as "normal" crimes without identifying the element of prejudice.

Important improvements in the legislation in regard to hate crimes have been developing due to the important role the OSCE mission has played in this regard. This mission has invested in the creation of a particular system of identifying hate crimes, which has been developed and implemented by the Helsinki Committee in RM, an NGO which has closely worked on this issue for several years. The OSCE mission has also supported the creation of the National Group on Hate Crimes that has developed the proposed amendments to the Criminal Code of RM. It is very important that these amendments are adopted by Parliament and become part of the positive legislation in Macedonia. 
However, there remains more to be done in regard to implementing the current provisions as well as putting the new amendments into practice. The government needs to create separate strategies and mechanisms of official identification and prosecution of hate crimes. These mechanisms need to be activated in the offices of the prosecutors and police in order for them to be able to identify, classify and prosecute hate crimes as separate forms of crime. The comparative approach found in the UK and in Croatia can be taken as examples of good practices in this regard.

Finally, it must be understood that tolerance needs to be invested in. It will not come naturally, rather, the state institutions will have to prove that they are interested in prosecuting hate crimes and in equally protecting their citizens from them.

\section{References}

Report on the comparative analysis of national legislations on hate crimes (2015). Skopje: Unpublished internal document prepared for the National Working Group on Hate Crimes.

Kanevcev, Metodija, Criminal Code - updated integral text (Stobi Trejd: (2015).

Vlado Kambovski, Criminal Law - General Part (Kultura 2004).

Vlado Kambovski, Commentary on the Criminal Code or Republic of Macedonia (Matica 2011).

Vlado Kambovski, Draft-amandments on the provisions of the Criminal Code that refere to hate crimes. (Skopje 2016) Unpublished internal document prepared for the National Working Gorup on Hate Crimes.

Gordan Kalajdziev, Gordana Buzarovska, Criminal Procedure Code (Akademik 2011).

Agenda of the Study Visit of NWGHC in Zagreb, June 1-3. (2015). Unpublished internal document prepared for the National Working Group of Hate Crimes in RM.

Besa Arifi, 'Hate Crimes in UK and in Poland - A Comparative Analysis' (2015). Skopje: Unpublished internal document prepared for the National Working Group on Hate Crimes.

Besa Arifi 'Presidential Pardon Debunks Fragility of Macedonian State Institutions' (Balkans in Europe Policy Blog 9 June 2016) <http://www.suedosteuropa.uni-graz.at/biepag/node/220> accesed: 25 June 2016.

Besa Arifi 'Rights of Victims of Hate Crimes' (2015) Second International Scientific Conference, Social Change in the Global World - Proceedings (217-230).

HM Government London UK. Delivering the Government's hate crime action plan. (2014). Challenge It, Report It, Stop It.

Helsinki Committee for Human Rights in RM. 'Observation, mapping and information on hate crimes, special analysis for the year 2013’. Skopje: 2014 Helsinki Committee for Human Rights in RM.

Helsinki Committee for Human Rights in RM. 'Annual report on hate crimes in the Republic of Macedonia for 2014'. Skopje 2015: Helsinki committee for human rights of the Republic of Macedonia.

Identoba and Others v. Georgia, 73235/12 (ECtHR May, 2015).

Vlado Kambovski, 'Proposal for the formation of a working group for the revision of the legal provisions concerning hate crimes and preparation of recommendations for their implementation by competent institutions'. Skopje 2015: Unpublished internal document prepared for the National Working Group on Hate Crimes. 
OSCE-ODIHR. 'Comments on Draft Amendments to Certain Provisions of the Criminal Code of the Former Yugoslav Republic of Macedonia Regarding Bias-Motivated Crimes based on an unofficial English translation of the draft amendments provided by the OSCE Mission to Skopje'. Warsaw 2016: OSCEODIHR.

OSCE-ODIHR. Hate Crime Laws A Practical Guide (Warsaw 2009).

Project for the American Jewish Committee Berlin, Study on National Legislative Efforts to Prevent and Combat Hate Crime. Berlin (Hogan Lovells International LLP, 2009).

The European Commission, 'The Former Yugoslav Republic of Macedonia 2013 Progress Report'. (16 Ovtober 2013) Accessed 7 August, 2016, from European Commission: http://ec.europa.eu/enlargement/pdf/key_ documents/2013/package/mk_rapport_2013.pdf

The European Commission. (2014, October 8). The Former Yugoslav Republic of Macedonia 2014 Progress Report. Retrieved August 7, 2016, from The European Commission: http://ec.europa.eu/enlargement/pdf/ key_documents/2014/20141008-the-former-yugoslav-republic-of-macedonia-progress-report_en.pdf

The European Commission. (2015, November 11). The Former Yugoslav Republic of Macedonia 2015 Progress Report. Retrieved August 7, 2016, from The European Commission: http://ec.europa.eu/enlargement/pdf/ key_documents/2015/20151110_report_the_former_yugoslav_republic_of_macedonia.pdf

UN General Assembly, Human Rights Council. (2014, March 26). Report of the Working Group on the Universal Periodic Review* The former Yugoslav Republic of Macedonia. Retrieved August 8, 2016, from UN Human Rights Office of the High Commissioner: https://documents-dds-ny.un.org/doc/UNDOC/GEN/G14/125/78/ PDF/G1412578.pdf?OpenElement

Winterbourne View 'abuse' hospital closes on Friday. (2011, June 24). Retrieved August 9, 2016, from BBC News: http://www.bbc.com/news/uk-england-bristol-13891855

Winterbourne View 'failed to protect people'. (2011, July 18). Retrieved August 9, 2016, from BBC News: http://www.bbc.com/news/uk-england-bristol-14181646 